$<$ 原 著 $>$

日本病理剖検輯報に基づく原発性胆汁性肝硬変の統計的観察

一昭和 59 ～62年間の全国 PBC 剖検例一

円山 英昭* 岩崎 信二** 大西 三朗**
山本 泰猛

要 旨：PBCの末期の病像を明らかにするため最近 4 年間（昭和59 62年）の日本病理剖検輯 報に報告された PBC 例を集計し，統計的に観察した，PBCの剖検は，全剖検症例(159,190例)

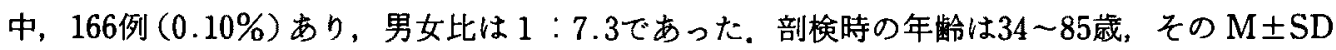

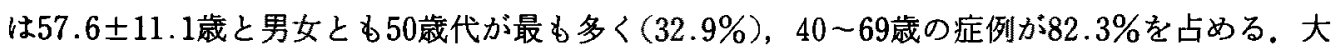
多数の症例は門脈王六進症や黄疸を合併した肝硬変期にある。肝重量は470２,400g の間に分 布し，萎縮型肝硬変像を呈する例が少くない，肝細胞癌の合併は， 7 例 $(4.22 \%)$ に見られる. その合併率は，この 4 年間， 1 年毎に上昇し，とくに男性 PBC 例は女性例に比して肝細胞癌合 併率が高い. 自己免疫疾患の合併は少い. PBC 剖険例では, 臨床診断と病理解剖学的診断の不 一致例がなお相当数あり，末期 PBC の病理解剖学的診断基準の確立が望まれる.

系引用語：原発性胆汁性肝硬変 病理解剖 病理解剖学 統計的研究

\section{緒 言}

原発性胆汁性肝硬变 (primary biliary cirrhosis, PBC)は，本邦では臨床診断基準 ${ }^{11}$ が確立した昭和50年 以降，臨床および剖検症例が漸増し，現在，主に臨床 事項の检討からその病態が解明されつつある. 今回, 末期 PBC の病像を剖検症例から明らかにすることを 目的として，最近 4 年間(昭和59年～62年間)，日本病 理剖検輯報に報告された $\mathrm{PBC}$ 例の記載事項を集計 し, 剖検症例における PBCの臨床および病理解剖学 的猃断の対比, PBC の剖検例の頻度 (年代別, 性別, 年龄別拈よび他の型の肝硬变との比較), 肝病変の性 状，合併症，副所見や死因について統計学的に観察し た. 一方では, 昭和33 58 年, 26 年間の本邦の $P B C$ 剖 検症例について同様の観察を行った前回の調査結果 ${ }^{2}$ と比較し, PBC 剖険例の臨床および病理解剖学的診断 の一致率, 剖検頻度, 性比, 剖険時年齢甲肝細胞癌合 併率などの経年的傾向を考察した。なお，輯報記載事 項の集計と考察に際しては，症例間で客観的差異のほ かに，字数制限と記入者の主観的判断に基つく内容の 不均一性が生じる可能性は留意しておく必要がある。

- 高知医科大学第 1 病理

**同第 1 内科

\section{材料と方法}

日本病理学会刊行の日本病理剖娭輯報 (第27 30輯) に報告された昭和59年から62年までの 4 年間の全剖検 例（検討中の症例を除く）159,190例から病理解剖学的 診断が PBC の症例 ( 4 例は腹部の又の局所解剖例) 抽出し，その記載事項を集計し，検討した。なお，剖 娭総数や $\mathrm{PBC}$ 以外の他の型の肝硬変の剖検数は, 各 剖検輯報巻末の総括表より集計した。

$$
\text { 結果 }
$$

1. 剖検例における PBC の蹦床診断と病理解剖学 的診断 (Table 1)

全剖検例中, 臨床診断が PBCであるのは152例（A 群)，その内訳は：

原発性胆计性肝硬変（定） 148例

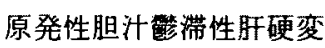
3 例

原発性胆汁性肝硬変疑 1 例 である。一方, 病理解剖学的診断が PBCである症例 $(B$ 群）は，次の166例である；原発性胆汁性肝硬变（症） (159例), 原発性胆汁性肝硬变疑（4例）, 原発性胆汁

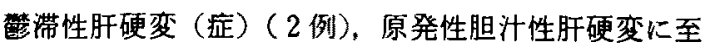
る過程 ( 1 例).

この166例は,いずれも主病診断名であり，病理解剖 学的には副所見として記載されているPBC例はな

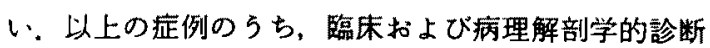


Table 1 Relation between pathological and clinical diagnosis of $\mathrm{PBC}$ in autopsy cases.

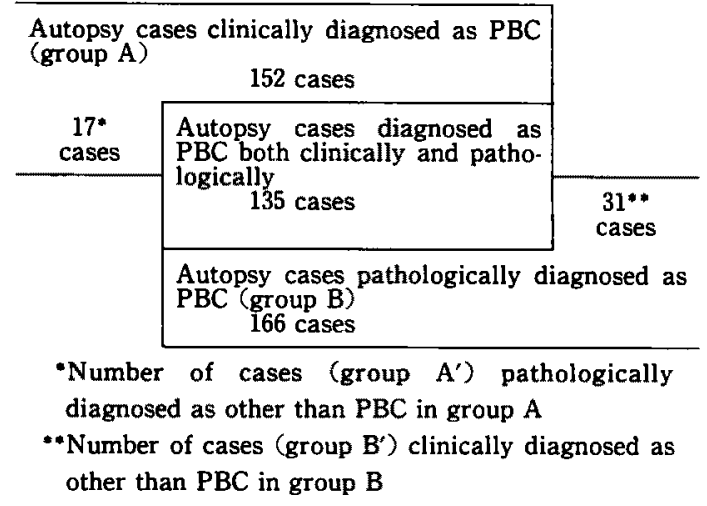

が共にPBCである症例は135例であり，臨床診断が PBC である152例(A 群)中の17例，病理解剖学的診断 が PBCである166例（B 群）中の31例は，両診断が一 致しておらず, 診断の不一致率は，A 群で $11.2 \%, \mathrm{~B}$ 群
では18.7\%である、各群毎に，診断不一致例をまとか てみると：

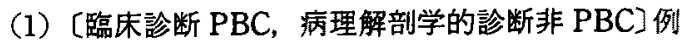
( $A^{\prime}$ 群). $A^{\prime}$ 群17例の病理解剖学的診断は；

肝硬変 〔12例：NOS (not otherwise specified) (2), 甲型 (1)，甲型 (2)，乙型 (1)，乙型 (6，その 亏ち，細胆管炎性肝炎，肝広範壊死，胃癌術後各1)], 胆汁性所硬変 [ 1 例], 胆汁凿滞性肝硬变十甲状腺癌 [ 1 例〕，萎縮性胆汁滞性旰硬変十右肺結核〔 1 例]，脺 管癌の疑い（肝内胆汁專滞）[1例]，粟粒結核症＋壊 死性出血性膵炎 [1 例]，と肝硬变が15例 (88.2\%) で 大半を占める.なかでも，通常型肝硬変の甲，乙分類 に従って診断されている例が多く，乙型肝硬変の診断 は $\mathrm{A}^{\prime}$ 群中， 6 例 $(35.3 \%)$ と最も多い。その他に，胆 汁性肝硬変の診断が 3 例离る。

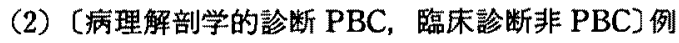
(B'群).この $\mathrm{B}^{\prime}$ 群31例の臨床診断は次の通りである；

肝硬変 (14例), 胆汁性肝硬変 ( 8 例), 肝不全 ( 2

Table 2 Number of autopsy cases with PBC and PBC cases associated with HCC and autopsy rates in Japan, from 1984 to 1987.

\begin{tabular}{|c|c|c|c|c|c|}
\hline & $\begin{array}{l}\text { No. of autopsy } \\
\text { cases } \\
\text { (A) }\end{array}$ & $\begin{array}{l}\text { No. of autopsy } \\
\text { cases with PBC } \\
\text { (B) }\end{array}$ & $\begin{array}{l}\text { No. of } P B C \\
\text { with HCC } \\
\text { (C) }\end{array}$ & $\begin{array}{l}\mathrm{B} / \mathrm{A} \\
(\%)\end{array}$ & $\begin{array}{l}\mathrm{C} / \mathrm{B} \\
(\%)\end{array}$ \\
\hline \multirow{4}{*}{184} & 39.713 & 42 & 1 & 0.11 & 2.38 \\
\hline & 24.361 & 5 & 1 & 0.02 & 20.0 \\
\hline & 15,109 & 37 & 0 & 0.24 & 0.0 \\
\hline & 243 & 0 & 0 & 0.0 & 0.0 \\
\hline \multirow{4}{*}{ '85 } & 40,154 & 37 & 1 & 0.09 & 2.70 \\
\hline & 24.614 & 5 & 0 & 0.02 & 0.0 \\
\hline & 15,428 & 32 & 1 & 0.21 & 3.13 \\
\hline & 112 & 0 & 0 & 0.0 & 0.0 \\
\hline \multirow{4}{*}{$' 86$} & 39,924 & 38 & 2 & 0.10 & 5.26 \\
\hline & 24.734 & 3 & 0 & 0.01 & 0.0 \\
\hline & 15,093 & 35 & 2 & 0.23 & 5.71 \\
\hline & 97 & 0 & 0 & 0.0 & 0.0 \\
\hline \multirow{4}{*}{ '87 } & 39,399 & 49 & 3 & 0.12 & 6.12 \\
\hline & 24,526 & 7 & 1 & 0.03 & 14.29 \\
\hline & 14,785 & 41 & 2 & 0.28 & 4.88 \\
\hline & 88 & 1 & 0 & 1.14 & 0.0 \\
\hline \multirow{5}{*}{$\begin{array}{l}\mathrm{T} \\
\mathrm{o} \\
\mathrm{t} \\
\mathrm{a} \\
1\end{array}$} & 159,190 & 166 & 7 & 0.10 & 4.22 \\
\hline & 98.235 & 20 & 2 & 0.02 & 10.00 \\
\hline & 60.415 & 145 & 5 & 0.24 & 3.45 \\
\hline & 540 & 1 & 0 & 0.19 & 0.0 \\
\hline & $\underset{=1.6}{M} \vdots_{1} F$ & $1: 7.3$ & $1: 2.5$ & $1: 12$ & $2.9: 1$ \\
\hline
\end{tabular}

* $T, M, F$ and $U$ indicate autopsy numbers of total, male, female and sex-unknown cases, respectively 
例)，その他(各 1 例：黄店，原発性硬化性胆管炎の疑 い，胆管癌，虚血性大腸炎，突然死＋子宮肪腫，原発 性フミロイドーシス, 記載潩れ)

B'群では肝硬変 $(45.2 \%)$ と胆汁性肝硬変 $(25.8 \%)$ が大部分を占める.

\section{PBC の剖検頻度 (Table 2)}

(1) 年度別 PBC 剖検頻度. 4 年間の全剖検数は 159,190 例(男性 98,235 ，女性60,415，性別未記入540) である，各年度とも，男性剖検例が常に多く，総剖検 例での男女比は1.6：1 となる。.PBC 166例は全剖検数 の0.10\%を占める。.この 4 年間では，剖検総数に対す る $\mathrm{PBC}$ の剖検頻度は，0.09 0.12\%の間を上下して おり，目立った増減はない。

（2）性別 PBC 剖検頻度. PBC 剖検例の性別内訳は, 男性20例，女性145例（1 例は性別未記入），男女比は $1: 7.3$ となる. 一方, 性別剖検総数に占める $\mathrm{PBC}$ 剖 検数の割合は，男性 PBC 例が男性総剖検数の $0.02 \%$ であるのに対して，女性は $0.24 \%$ となり，性別剖娭数 に対する男女の $\mathrm{PBC}$ 剖検率の性比 (男：女) は $1: 12$ となる。一方，男性，女性例とも，この 4 年間では， PBC 剖梌頻度に, とくに変化はない。

3. 剖検時年龄 (Table 3)

剖検時の年齢は，34歳（女性，局所解剖例。抗系粒 体抗体, 抗 DNA 抗体, 抗マイクロゾーム抗体がいずれ も陽性。食道静脈癉，胆汁性ネフローゼを合併）から 85歳（女性. 臨床訩断：胆管癌，肝重量 $470 \mathrm{~g}$ ）の間に 分布しており，平均年齢士標準偏差 $(\mathrm{M} \pm \mathrm{SD})$ は57.6土
Table 3 Age distribution of 164 autopsy cases with $\mathrm{PBC}$.

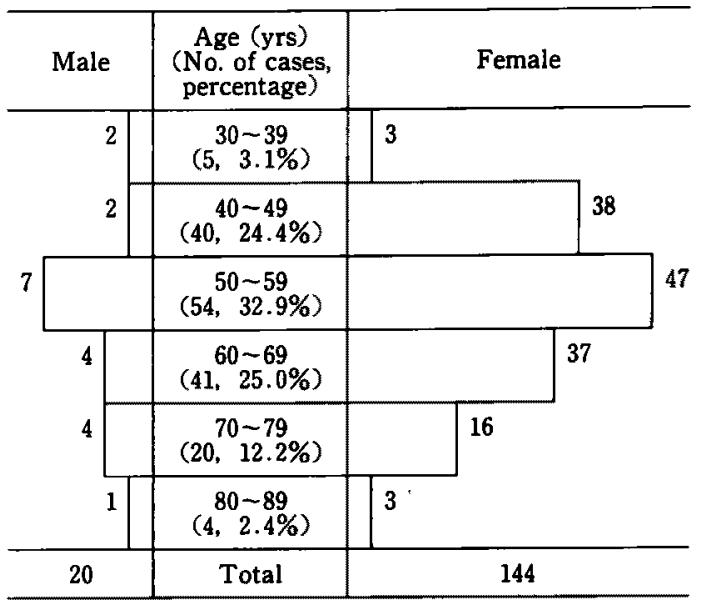

One case with sex-unknown and another female case with unknown age are not included

11.1歳である．性別では，男性59.9 12.6歳，女性 $57.3 \pm 10.9$ 藏となり，男女とも50歳代が最を多い。つ いで60，40歳代の症例が多く，40６9歳の症例が PBC 剖検数の $82.3 \%$ 占める。年度別 $\mathrm{M} \pm \mathrm{SD}$ は，昭和 59 年 度 $55.8 \pm 11.9,60$ 年度 $58.4 \pm 10.8,61$ 年度 $58.5 \pm 9.1$, 62 年度 $57.5 \pm 11.9$ 歳である.

4. 他の型の肝硬变剖模例との剖榙頻度の比較 (Table 4)

PBC の剖検数を 1 とすると, 乙型肝硬变 39.7, 肝硬

Table 4 Number of patients with various types of liver cirrhosis recorded in the Annuals of Pathological Autopsy Cases in Japan, 1984-1987.

\begin{tabular}{|c|c|c|c|c|c|c|c|c|c|}
\hline & \multirow{2}{*}{$\begin{array}{l}\text { total no. } \\
\text { of autopsy }\end{array}$} & \multirow{2}{*}{$\mathrm{PBC}$} & \multirow{2}{*}{$\begin{array}{c}\text { cirrhosis } \\
\text { NOS* }\end{array}$} & \multicolumn{4}{|c|}{ Type of cirrhosis** } & \multirow{2}{*}{$\begin{array}{l}\text { alcoholic } \\
\text { cirrhosis }\end{array}$} & \multirow{2}{*}{$\begin{array}{l}\text { congestive } \\
\text { cirrhosis }\end{array}$} \\
\hline & & & & A & $A^{\prime}$ & B & $\mathrm{B}^{\prime}$ & & \\
\hline Male & 98.235 & 20 & 1,912 & 611 & 545 & 4,954 & 631 & 575 & 86 \\
\hline Female & 60,415 & 145 & 614 & 228 & 193 & 1,615 & 216 & 64 & 49 \\
\hline Unknown & 540 & 1 & 5 & 2 & 2 & 20 & 2 & 2 & 0 \\
\hline Total & 159.190 & 166 & 2,531 & 841 & 740 & 6,589 & 849 & 641 & 135 \\
\hline Ratio to PBC & 959 & - & 15.2 & 5.1 & 4.5 & 39.7 & 5.1 & 3.9 & 0.8 \\
\hline male/female & 1.6 & 0.1 & 3.1 & 2.7 & 2.8 & 3.1 & 2.9 & 9.0 & 1.9 \\
\hline \multicolumn{10}{|l|}{$\begin{array}{l}\text { Ratio to no. } \\
\text { of all autopsy } \\
\text { in each sex }\end{array}$} \\
\hline male (\%) & & 0.02 & 1.95 & 0.62 & 0.56 & 5.04 & 0.64 & 0.59 & 0.09 \\
\hline female $(\%)$ & - & 0.24 & 1.02 & 0.38 & 0.32 & 2.67 & 0.36 & 0.11 & 0.08 \\
\hline (male/female) & & $(0.08)$ & (1.9) & $(1.7)$ & (1.7) & $(1.9)$ & (1.8) & $(5.5)$ & $(1.1)$ \\
\hline
\end{tabular}

-NOS = not otherwise specified

-"classified according to Miyake's classification ${ }^{3)}$ 
変 NOS 15.2, 乙型肝硬变および肝線維症5.1, 甲型

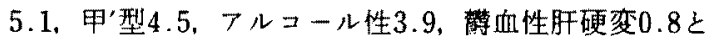
なる．また，各型の肝硬変剖検数の性比は，女性例の 多いPBC とは対照的に，フルコール性肝硬変 $9.0 ： 1$ を最高に, 乙型肝硬変と肝硬変 NOS はいずれも 3.1 ： 1, 乙型肝硬変扰よび肝線維症2.9：1，甲型2.8： 1, 甲型2.7：1 と男性剖検例の方が多い。なお，性別 剖検数に占める各型の肝硬変の剖検率の男女比を Table 4 k示す.

\section{5. 肝病变}

(1) PBC の病期.34例に記載があり,Scheuer 分類 では，II期 1 例（49歳，女性. 肝重量 $1.800 \mathrm{~g}$, 脾重量 $970 \mathrm{~g}$ ), III期（線維化期，瘕痕期，前硬変期を含める） 7 例，III IV 期 2 例，IV期（硬変期，終末像，末期と 記載された症例を含める）24例である。

(2) 肝重量 (Table 5)。166例中，120例に肝重量の

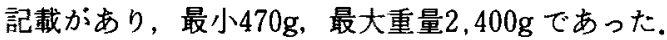

(3) 肝細胞癌の合併 (Table 2)。166例中, 7 例 (4.22\%)に肝細胞癌の合併がある。昭和59年より62年 までの年度每の合併頻度は $2.38 \% ， 2.70 \% ， 5.26 \%$, $6.12 \%$ と経年毎に増加している。肝細胞癌合併 PBC 7 例の, 年齢, 性, 住所; 肝重量：肝細胞癌の性状, 浸潤・転移の有無は次のよ5になる(年齢順)；(1)54歳， 女性, 三重県：710g：索状型, Edmondson I 度, 浸潤・ 転移な乚。(2)58歳，男性。高知県：1,100g：多結節型, 最大径 $5 \mathrm{~cm}$, 右葉, 索状型, 浸潤・転移なし. (3) 59 歳, 女性。岐阜市：Edmondson II 度，両肺に転移，門脈に 浸潤. (4)66歳, 女性, 高知市：750g：右葉, Edmondson II 度。浸潤・転移なし(腹部局所解剖)。(5)75歳，女性， 福井市：960g：小, 単発, 浸潤・転移なし. (6)76歳, 女性。涉谷区；肝細胞癌之胆管細胞癌の混合型，浸潤転移なし。(7800歳，男性，高知県：740g：孤在結節型， 浸潤・転移なし。

また，肝細胞癌合併率は女性 PBC 例が3.45\%であ

Table 5 Liver weight of 120 autopsy cases with PBC.

\begin{tabular}{c|c}
\hline weight of livers & No. of cases \\
\hline $0 \sim 500 \mathrm{~g}$ & 4 \\
$501 \sim 999 \mathrm{~g}$ & 45 \\
$1.000 \sim 1.499 \mathrm{~g}$ & 47 \\
$1.500 \sim 1.999 \mathrm{~g}$ & 18 \\
$2,000 \sim 2.499 \mathrm{~g}$ & 6 \\
\hline Total & 120 \\
\hline
\end{tabular}

るのに対して男性例は $10.0 \%$ と,上り高い合併を示す。

(4) 門脈病変は 5 例比記載があり, 門脈硬化症 3 例, 門脈血栓症 3 例である。

\section{6. 合阱症および副病変}

(1) 原発性肝癌以外の悪性腫場の合併. 166例中, 8 例 $(4.8 \%)$ ）認めら九，甲状腺癌 3 例 $(1.8 \%)$ 胃癌 2 例 $(1.2 \%)$ 肺癌，乳癌，子宮癌，前立腺癌各 1 例 (0.6\%；重複癌を含む)で，全例，浸潤·転移はない。

(2) $\mathrm{PBC}$ 以外の主病診断名. $\mathrm{PBC}$ 剖検例，166例中 139例は主病診断名として，PBC のみが記載されてい る.他の27例では，PBC と共に，他疾患も主病猃断名 の項に記載されている，その診断名は，上述の肝細胞 癌（7 例） と原発性肝癌以外の悪性腫瘍（8 例）のほ かに食道静脈瘤破裂塞栓療法および血流遮断術後, 全 身性粟粒結核症，再生不良性貿血，シェーダレン症候 群，情尿病，脾腫 $(280 \mathrm{~g})$ ，急性出血性膵炎，特発性心 筇症, 間質性肺炎, フスペルギールス症, 脾腫 $(440 \mathrm{~g})+$ 黄㾞，続発性アミロイドーシス各1例である。

（3）自己免疫性疾患. シェーダレン症候群 6 例. 他 に筫下腺炎，顎下腺萎縮，慢性顎下腺炎，唾液腺炎な と，唾夜腺病变が各 1 例記載されていた。生た，慢性 甲状腺炎 4 例，橋本氏病が 1 例あり，その他に，甲状 腺線維化の診断が 1 例名られた。しかし，慢性関節り ウマチやその他の自己兔疫疾患の記載はない。

（4）膵炎。記載23例中，急性膵炎は11例（2 例は直 接死因)，慢性膵炎10例，膵资 NOS は2 例であった。

(5) 門脈王え進症および関連病変. 門脈圧方進症上 して 6 例, 脾臓の病変としては, 脾腫, 慢性脾節血あ

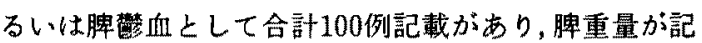
載されている74例中 46 例は400g 以上で，最大脾重量は 970gであった。 食道静脈瘤が記載されている89例中。 20例は破裂し，5例は離断術および塞栓術後状態であ る、腹水は80例に記載されており，最大 $7,000 \mathrm{~m} /$ の腹 水の貯留があった。

（6）黄㾝（胆汁性ネフローゼ，黄疸性腎症を含む） は101例に記載されている。

（7）その他の合併症および副所見を記載頻度順にな らべると, 出血傾向および臟器出血 (49例), 肺炎 (気

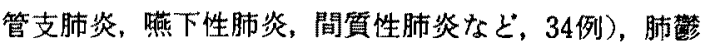
血, 水腫 (28例)，胃漬湯的上び糜爛（25例），真菌症 (10例)，胆石症 ( 7 例)，十二指腸潰㾮 ( 5 例)，骨粗

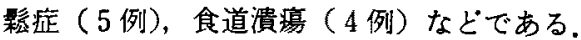

\section{7. 面接死因}

46例に記載が見られ，食道静脈瘤破裂による死亡が 
最も多い(14例)，以下，肺の炎症(肺资, 気管支肺炎,

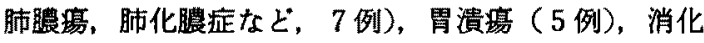
管出血 ( 5 例)，黄㾞および黄瘨留症 ( 4 例)，全身性 真菌症 ( 3 例)，急性脺炎 ( 2 例), 肺䢔血，水腫 (2 例)，肺出血（2 例)，乙の他に急性堅孟腎炎，虚血性 晹炎，細菌性心内膜炎，血浆交換後の敗血症，脳出血， 右胸腔内括よび腹腔内出血，十二指腸潰瘍，急性肝・ 腎壊死が各 1 例である。

\section{考察}

\section{1. 剖検症例における PBCの䦭床およひ病理解剖} 学的診断

PBCは，わが国では昭和50年に現行の PBC 臨床診 断基準が提唱されれ，その全国的な採用と PBC の診断 を確定するために肝臟の wedge biopsy が実施される 機会が多くなったことにより，臨床症例数は増加し， あわせて，昭和51年以降，剖娭数も漸增している゙2．し かしながら，剖検症例からみると，PBCの臨床および 病理解剖学的猃断が一致していない症例はなお相当数 あり, 昭和33～58年, 26年間の全国 PBC 剖検症例につ いて同様の観察を行った前回" よび病態の特徵が臨床サイドのみならす病理解剖学的 にも，より広く理解されるようになった最近 4 年間の 今回の観察結果とを比較しても，両診断の不一致率は 明らかな減少の傾向にない(Table 6)。すなわち，臨 床部断が PBCである症例 (A 群)のうち，病理解剖学 的猃断が $\mathrm{PBC}$ 以外である症例 ( $\mathrm{A}^{\prime}$ 群)の割合は, 前回
$8.4 \%$, 今回 $11.2 \%$ と診断不一致の症例は，むしろ増加 している。一方, 病理解剖学的彭断が PBCである症例 (B 群)のうち, 臨床診断が PBC 以外である症例 ( $\mathrm{B}^{\prime}$ 群）の割合は, 前回 $25.3 \%$ ，今回 $18.7 \%$, 僅かな滅 少がうかがわれるが，不一致率は今回も依然として高 い. PBC 剖検例において, 臨床詥断之病理解剖学的診 断の不一致が生じるのは, 日本剖検輯報の臨床診断記 載欄の字数制限（出所と併せて16文字）のためとは考 点難い，A群に見られる診断不一致の原因としては， 現行の臨床診断基準 $x^{\circ}$ ，(1)病理組織学的に PBCK pathognomonic な慢性非化膿性破壊性胆管炎 (chronic non-suppurative destructiv echolangitis, CNSDC)の像引を認め, 臨床経過や臨床所見も PBCの 臨床像を呈する定型的な PBC 例のほかに, (2)組織学 的に，CNSDC の所見を欠いていても，PBCに矛盾し ない像を示す例，さらに，(3)組織検查が未施行例でも， 抗系粒体抗体が陽性で，臨床経過からPBC と考えら れる症例をも，PBC の確定診断を容認しているため, PBCの臨床診断下に, classical PBCのほかに, 臨床 像が PBC に類似する近縁病变が含主れている可能性 がある。また，一つには，特殊型肝硬変の一型である PBC の末期像が古典的な肥大型肝硬変像の注かに, 相 当数の症例において，萎維型肝硬変像を呈すること， また通常，肝線維症の段階にとどまることが多い続発 性胆汁性肝硬変と比較して, PBC 例では肉眼的に結節 形成が明瞕になることがあるため6)、病理解剖学的に

Table 6 Comparison between previous report and present study.

\begin{tabular}{l|c|c}
\hline & $\begin{array}{c}\text { previous report }^{2)} \\
(1958-1983)\end{array}$ & $\begin{array}{c}\text { present study } \\
(1984-1987)\end{array}$ \\
\hline $\begin{array}{l}\text { Diagnosis of PBC: } \\
\text { 1. Pathological diagnosis in group A }\end{array}$ & 91.6 & 88.8 \\
a. PBC (\%) & 8.4 & 11.2 \\
b. Other than PBC (\%) & 74.7 & 81.3 \\
2. Clinical diagnosis in group B & 25.3 & 18.7 \\
$\begin{array}{l}\text { a. PBC (\%) } \\
\text { b. Other than PBC }\end{array}$ & $\begin{array}{l}\text { (1:5.1 } \\
\text { Incidence of autopsy with PBC (\%) }\end{array}$ & $1: 7.3$ \\
\hline Sexual ratio of autopsy cases with PBC & $0.06 \%$, from & 0.10 \\
(M : F) & $53.9 \pm 11.8$ & $57.6 \pm 11.1$ \\
\hline Age (M \pm SD) at autopsy & 2.10 & 4.22 \\
\hline $\begin{array}{l}\text { Incidence of association with HCC } \\
\text { among PBC cases (\%) }\end{array}$ &
\end{tabular}

Group A : autopsy cases clinically diagnosed as PBC

Group B : autopsy cases pathologically diagnosed as PBC

HCC : hepatocellular carcinoma 
は、結節形成を示す肝资ウイルスやフルコールなどに 上る通常型肝硬変と，とくに，肉眼的鑑別が困難なこ とも診断不一致の原因と考えられる。的た， PBCは， 本来 Jonesらの主張》のよ5に, 病理形態学的には “distinctive entity”をあらわするのではないのかむし れない、いずれにせよ，剖検例に扣ける PBC の郜床お よび病理解剖学的診断を適合させるためには, PBCの 先患単位としての均質性の有無を臨床および病理解剖 学的に再評価することが必要である。

剖検の対象となる $\mathrm{PBC}$ 例の多くは硬変期にあり， CNSDC 像の出現頻度は減少する.そのため, 病理学的 には，肝缄の計測，結節の性状についての肉眼所見や 軟 X 線写真撮影による肝内胆管造影所見などを参考 に，各部位から多数の切り出しを行い，光顕的に

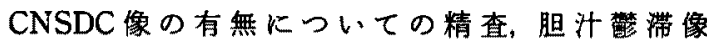
(peripheral cholestasis) p偽小葉の形状（jigsaw puzzle 様) の観察, 連続切片による肝内胆管枝の再構 案と肝内小胆管の減少についての半定量的観察8)，偽 小葉周辺部肝細胞の Mallory 体の出現や銅の沈着の 証明と沈着銅量の定量あるいは，免度組織学的技法に よる浸潤リンバ球の phenotype や胆管上皮上に表出 する HLA 抗原の観察などを踾床診断 PBC の剖検例 について行らことが必要である。それらの観察結果に 基づいて，特殊型肝硬変に属する $\mathrm{PBC}$ と通常型肝硬 変との異同を明らかにし，末期の PBCの病理解剖学 的診断基準を確立する必要がある。

\section{2. 剖検よりみた $\mathbf{P B C}$}

（1）剖検頻度. 剖検頻度は，前回（昭和33 58年, 26年間）の観察結果 ${ }^{2}$ と比較して增加している（p< $0.001 て ゙$ 有意)。この $\mathrm{PBC}$ 剖検率の增加は，PBCの臨 床診断基準が提唱され，PBCの剖検数が前年比で倍増 した昭和51年以降に限定した，昭和51年～58年の剖検 率 $(0.06 \%)$ と比較しても明らかである。一方，PBC 剖検例の男女比は, 前回の 1：5.1に対して今回は 1： 7.3と，とくに女性 PBC 例が増加しており，前回の結 果と比較すると, 今回の PBC 剖検総数の増加は, 主と して，女性例の増加による。この男女比は，臨床例”に おける性比（約 1：6）と大きな差異はない，一方， 最近の 4 年間では剖検頻度に目立った增减はなく， PBC の剖検は，本邦では，1，000例の剖検で約 1 例の割 合で行えれている，一方，剖険時の平均年龄は，前回 と比較して有意の差が認められ $(\mathrm{p}<0.001)$, より高龄 化を示す。また，男性 PBC 剖検例は，女性例に比して， より高齢である傾向は前回と同様であった。
（2）肝硬変，肝䁍は大多数の例で，門脈圧元進症や 黄疾を合併した肝硬变期にあり，Scheuer 分類へ第 II 期の例でも，すでに門脈圧方進症の合併が記載されて いる。肝重量は，重量が記載されている120例では，最 小 $470 \mathrm{~g}$ ，最大 $2,400 \mathrm{~g}$ と広い範囲に分布しており，一定 の傾向はない．しかも，1,000g 未满は49例， $1,500 \mathrm{~g}$ 以 上は24例であったこれらの事実は，PBCの疫学ある いは進展機序か，単一の，あるいは一様のものではな く，䍜病期間が長いため，自己免疫機序のほかに，C型 肝炎ウイルスの感染やその他の多数の因子に影幚され る複雑, 多彩なるのである可能性を強く示唆している.

PBC 剖検例の解析では，肝重量と病期が重要であ ろ. 今回の調查では, 肝重量は 46 例(27.7\%), 病期に ついては132例 $(79.5 \%)$ ，輯報上記載がない，特に 組織学的病期については，PBCは，非硬变期をも含め て PBCと診断されるため，症例毎に病期を明示する 必要がある.

$\mathrm{PBC}$ と肝細胞癌の合併は, 昭和59 62年の 4 年間の 剖検例では，通常型肝硬変，とくに，乙型肝硬变の高 率な肝細胞癌の合併と比較すると，はるかに低率では あるすのの，年度每に次第に増加し，前回の合併率 (2.10\%)と比較しても今回の肝細胞癌合併率 $(4.22 \%)$ はより高值であった．また，剖検例や臨床例の症例報 告数も増し ${ }^{10 \sim 15)}$ ，前硬变期の PBC に合併した肝細胞 癌の臨床報告もある ${ }^{16)}$.一方, 男性剖検例の肝細胞癌合 併率は， $10.0 \%$ であり，女性例の $3.45 \%$ と比較して高 い. PBC 剖検例における肝細胞癌合併率のこの性差 は, Lucey らの臨床例の報告 ${ }^{12}$ (男性 PBC 例の肝細胞 癌合併率 $10.3 \%$ ，女性例 $1.6 \% ， \mathrm{p}<0.01 ＼mathrm{~ 上 ほ ほ ゙ 同 様 ~}$ である．なお，今回，集計した 7 例中，1例にのみ浸 潤転移がある。

（3）合併症および副病変。原発性肝癌以外の悪性隀 瘍の合併は，いずれも稀であるが，同一期間の各癌の 剖検総数上比較すると，甲状腺癌（剖検総数 2,421 例） は $1 ： 807$ ，胃癌（剖検総数 14,982 例） $1: 7,491$ ，肺 癌 (剖検総数 15,470 例) $1: 15,470$, 子宮癌 (剖検総数 2,479 例)， $1: 2,479$, 前立腺癌（剖検総数 2,705 例） $1 ： 2,705$ となり，甲状腺癌と PBCの合併は，他の癌 と比較して高い，一方，女性例は年龄や性差を補正し た対照群と比較すると，乳癌の発生率が有意に高いこ

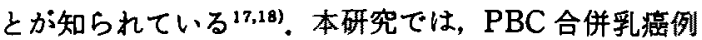
は，1例あり，その全乳癌剖検数 $(1,828$ 例)に対する 割合は $1: 1,828 て ゙$, 甲状腺癌合併 $\mathrm{PBC}$ 例に次ぐ比率 を示した。ちなみに，肝細胞癌のこの 4 年間の剖検数 
は, 11.622例であるので PBC 合併肝細胞癌 7 例の割 合は $1: 1,666$ となる。

以上の悪性尰陽は，隀瘍の大小に拘わらず，輯報に 記載されているか;，副病変の記入は，剖検医の判断に 委ねられており，その内容は一様ではない，しかし， 自己免疫疾患の合併例は，PBC臨床例19)での高率な合 併とは対照的に, 前回と同様, 記載例は少数で, シェレ グレン症候群, 橋本氏病（慢性甲状腺炎を含む）とる それぞれ，166例中わずかに 6 例と 5 例であった。 それ に反して, 膵炎の合併は臨床(例帛では177例中, 僅か 3 例であるのに対して, 剖倹例では166例中, 23例記载さ れており，11例の急性膵炎中，2 例は直接死因である.

（4）直接死因. 直接死因が明示されている例では, 前回と同様, 食道静脈瘤の破裂に上る死亡が最も多い.

（5）他の型の肝硬変との剖揄数の比較では各型の肝 硬変中, 最も多いのは, 乙型肝硬変，ついで、肝硬変 NOS, 乙'型扣ょび肝線維症, 甲型, 甲’型, アルコール 性肝硬变の順で，いずれす PBCょり剖検数が多い。逆

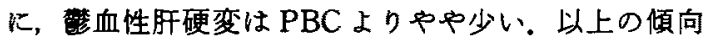
は，前回とは注同様である，剖検例の性比では，他の 型の肝硬変が剖検数の性比および性別剖検数に対する 剖検率の性比とむ，フルコール性肝硬変を最高に男性 例が多いのに対して, PBCのみ，女性例が戍倒的に多 いことが注目される。

\section{結語}

本邦に拈ける，最近の PBCの剖検は女性例, 50歳代 の症例が多数を占め, 剖検頻度はなお低い。大多数は 門脈圧穴進症を伴5肝硬変像を呈し, 直接死因は食道 静脈瘫破裂によることが多い：自己免疫疾患の合併例 は少いが，肝細胞癌合併頻度は漸增し，とくに男性 $\mathrm{PBC}$ 例でより高率である, 剖検時, PBCの臨床および 病理解剖学的診断を一致させるためには，末期 $\mathrm{PBC}$ の病理学的診断基準の確立之，個々の症例について担 当蹦休医と剖検医による十分な検討が必要である。

本論文の要旨は第26回日本肝脸学会総会で発表した。

謝辞 統計学的検定について御教示いたたいた広島大学 原医研統計学研究部門務中昌已教授, 橋本哲男先生, 資料の 整理に腳協力いただいた大原史子さんに感謝致します。

\section{文献}

1）市田文弘：原発性胆汁性肝硬变とその周辺. 日消 会誌 $72: 1428-1430,1975$

2）円山英昭，原弘：剖挨より見炕原発性胆汁性
肝硬変症一日本病理剖検輯報（昭和 33-58 年) に

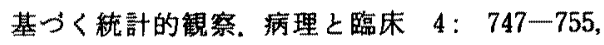
1980

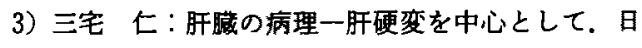
病会誌 $49: 589-632,1960$

4) Scheuer PJ : Primry biliary cirrhosis. Proc R Soc Med $60: 1257-1260,1967$

5) Rubin E, Schaffner F, Popper H: Primary biliary cirrhosis. Chronic non-suppurative destructive cholangitis. Am J Pathol 46: 387 $-407,1965$

6) 栄枝弘司, 西原利治, 藤川正直, 他：肝細胞癌を 伴った原発性胆汁性肝硬変の一例（付 原発性胆 汁性肝硬変70例に和ける血清 AFP)。肝藏 27 : $497-503,1986$

7) Jones WA, Tisdale WA: Posthepatitic cirrhosis clinically simulating extrahepatic biliary obstruction (so-called "primary biliary cirrhosis"). New Engl J Med 268 : 629-639, 1963

8) Nakanuma Y, Ohta G: Histometric and serial section observations of the intrahepatic bile ducts in priamry biliary cirrhosis. Gastroenterology $76: 1326-1332,1979$

9）井上恭一, 太田康幸, 恩地森一, 他：原発性胆计 性肝硬变 (PBC) 全国調查集計結果 (第 10 報). 厚生省特定知患難治珄の肝炎調查研究理, 平成元 年度研究報告, 8-10, 1989

10) Krasner N, Johnson PJ, Portman B, et al: Hepatocellular carcinoma in primary biliary cirrhosis: Report of four cases. Gut 20:255 $-258,1979$

11）高木文昭, 高橋 敦, 横山 武：原発性胆汁性肝 硬変に合併した肝細胞癌の 1 剖検例. 病理と臨床 $3: 664-668,1985$

12) Lucey MR, Neuberger JM, Williams R: Primary biliary cirrhosis in men. Gut $27: 1373$ $-1376,1986$

13）円山英昭，岩村伸一，渡辺誠司，他：肝細胞㴦を 伴5原発性胆汁性肝硬変症 (PBC) の 3 剖検例. 岡山医誌 $102: 261-263,1990$

14）市田隆文。波畘徽, 笹川哲哉, 他: 原発性胆 汁性肝硬変から見いたされた肝細胞癌.肝胆膵 $21: 969-975,1990$

15) Nakanuma $Y$, Terada $T$, Doishita $K$, et al : Hepatocellular carcinoma in priamry biliary cirrhosis: An autopsy study. Hepatology 11: 
1010-1016, 1990.

16) Gluskin LE, Guariglia P, Payne JA, et al: Hepatocellular carcinoma in a patient with precirrhotic primry biliary cirrhosis. J Clin Gastroenterol $7: 441-444,1985$

17) Wolke AM, Schaffner F, Kapelman B, et al : Malignancy in priamry biliary cirrhosis. High incidence of breast cancer in affected women.
Am J Med 76:1075-1078, 1984

18) Gouide BM, Burt $\mathrm{AD}$, Boyle $\mathrm{P}$, et al: Breast cancer in women with primary biliary cirrhosis. Br Med J 291 : 1597-1598, 1985

19）佐々木博, 市田文弘, 山本祐夫, 他：原発性胆汁 性肝硬变全国調查集計結果。厚生省特定疾患難治 性の肝炎調查研究班, 昭和 55 年度研究報告, 128 $-136,1980$

\title{
Autopsy cases of primary biliary cirrhosis in Japan - A statistical study based on the Annuals of the Pathological Autopsy Cases in Japan, from 1984-1987
}

\author{
Hideaki ENZAN*, Shinji IWASAKI**, Saburo ONISHI**, \\ Yasutake YAMAMOTo** and Hiroshi HaRA*
}

A total of 166 cases of PBC recorded in the Annuals of the Pathological Autopsy Cases in Japan, from 1984 to 1987 , were studied statistically. Its incidence among the total autopsy cases was $0.10 \%$. The mean age with S.D. (range) at autopsy was $57.6 \pm 11.1$ years (34-85). There was an overall female preponderance of 7.3:1. The majority of cases showed cirrhotic stage with portal hypertension and jaundice. The liver weight ranged from $470 \mathrm{~g}$ to $2,400 \mathrm{~g}$. The occurrence of HCC was recorded in 7 cases $(4.22 \%)$. Autoimmune diseases were rarely complicated. Some autopsy cases diagnosed clinically as $\mathrm{PBC}$ received a pathological diagnosis other than $\mathrm{PBC}$. It is necessary to determine the pathological criteria of $\mathrm{PBC}$ in the cirrhotic stage.

* Department of Pathology, Kochi Medical School (Nankoku)

** Department of Internal Medicine, Kochi Medical School (Nankoku) 